\title{
Maize flour parameters that are related to the consumer perceived quality of 'broa' specialty bread
}

\author{
Bruna CARBAS ${ }^{1}$, Maria Carlota VAZ-PATTO², Maria Rosário BRONZE2,3,4, Andreia BENTO-DA-SILVA², \\ Maria João TRIGO ${ }^{1}$, Carla BRITES ${ }^{1 \star}$
}

\begin{abstract}
A wide range of quality parameters have been used to describe maize flours for food use, but there is no general agreement about the most suitable parameters for breadmaking. The objective of this study was to identify the maize flour parameters related to the consumer perceived quality of Portuguese broa bread (more than $50 \%$ maize flour). The influence of eleven maize landraces was assessed and compared with commercial flour using baking tests. The broa were evaluated by instrumental (colour, firmness) and sensory hedonic analysis with a consumer panel of 52 assessors. The broa sensory analysis revealed similar assessments among landraces and the lowest scores for commercial flour. The flour particle size distribution is the major influence, with commercial flour showing the highest mean diameter and a large particle distribution range. Broa consumer panel linkage associations and specific sensory descriptors have been identified; age as an influence on colour, cohesiveness, and source region as an influence on appearance and texture.
\end{abstract}

Keywords: broa; maize; bread; consumer parameters; sensory analysis.

Practical Application: Maize landrace flours have a narrow particle size distribution and a positive impact on broa bread quality.

\section{Introduction}

Portugal was one the first European nations to adopt maize (Zea mays L.) in its agricultural system more than five centuries ago (Vaz Patto et al., 2009). Over time, maize has become highly integrated into the Portuguese agriculture, with the development of numerous landraces (open pollinated varieties, OPV) and its integration into the daily diet as the major grain for bread making in the mid-19th century (Justino, 1988).

Broa is Portuguese ethnic bread comprised of more than $50 \%$ maize flour mixed with either wheat or rye flours and is highly consumed in the north and central regions of Portugal (Brites et al., 2010). The bread making process is primarily empirical, and several types of broa can be produced depending on the type of maize and blending flours, although local OPVs are usually preferred (Vaz Patto et al., 2007).

There are many recipes used to prepare broa, but the traditional process (Brites et al., 2007) involves adding maize flour (sieved whole meal flour), hot water, wheat flour, yeast and leavened dough from a previous broa (acting as the sourdough). After mixing, resting and proofing, the dough is baked in a wood-fired oven. This empirical process leads to an ethnic product highly accepted for its distinctive sensory characteristics (Brites et al., 2007) and provides an interesting source of nutritional value due to its lower glycaemic index compared to wheat bread (Brites et al., 2011).
A general consensus has been reached regarding the classification of breads according to the degree of hydration of their dough, the presence or absence of fats and instrumental analysis, including loaf weight and volume, colour and textural parameters (Matos \& Rosell, 2012).

The sensory quality of bread is evaluated by the human senses of sight, smell, taste, hearing and touch (Meilgaard et al., 1999) and can be evaluated by effective (e.g., consumer preference) analytical methods (Callejo, 2011). Relationships between bread composition and instrumental evaluations have been detected (Callejo, 2011).

However, bread quality is influenced by many factors in the production chain, from grain cultivation to bread packaging (Kihlberg et al., 2006), and individual consumer perceptions may be influenced by social, demographic and product experiences, primarily in the case of traditional breads.

The aim of this study was to understand the influence of local maize landrace OPVs in broa quality and to contribute to the development of specific vocabulary as sensory descriptors for this type of bread. Twelve maize flours were used in baking tests, and the broa have been analysed by instrumental methods and evaluated by a consumer sensory panel. 


\section{Material and methods}

\subsection{Samples}

Maize OPVs samples

Eleven maize OPVs representatives of the diversity of germplasm participatory breeding program (Vaz Patto et al., 2013) were selected and reproduced in 2011 under controlled trials conducted at Agrarian School of Coimbra. The maize samples from the white type (Algarro, Bastos, Broa 57, Pigarro, Sinpre and Verdial da Aperrela) and yellow type (Aljezudo, Amiúdo, Broa 213, Castro verde and Fandango) were kindly provided by Mendes-Moreira and evaluated in baking tests to produce traditional broa.

\section{Maize flours}

Whole meal maize flour was obtained after milling the grain in an artisan water mill with millstones (Moinhos do Inferno, Viseu). Commercial maize flour (Nacional type 175) was also included to produce broa.

\section{Maize flours particle size}

Particle size distribution was characterised using the AACC method 55-40.01:1999 (American Association of Cereal Chemists, 1999), with a Malvern multi-channel laser light-scatter instrument, a medium diameter percentile setting $\left(\mathrm{d}_{0.1}, \mathrm{~d}_{0.5}, \mathrm{~d}_{0.9}\right)$ and volume weighted mean $\mathrm{D}[4.3]$ expressed in $\mu \mathrm{m}$.

\subsection{Bread formulations}

The base broa formulation described previously (Brites et al., 2011), included $70 \%$ maize, $20 \%$ rye, $10 \%$ wheat flours, $2.8 \%$ sugar, $1.76 \%$ salt, $1 \%$ dry yeast and $10 \%$ sourdough (wt/wt. flour basis) and $100 \%$ (vol/wt. flour basis) water.

\subsection{Baking procedures}

The Broa bread making process described previously (Brites et al., 2011), consisted of mixing the maize flour with $80 \%$ boiling water containing $1.76 \%$ salt and kneaded for 5 minutes (Ferneto AEF035). The dough was allowed to rest and cool to $27^{\circ} \mathrm{C}$, and the remaining ingredients (sugar, salt, dry yeast, sourdough) including $20 \%$ water were added. The dough was again kneaded for 8 minutes and left to rest for bulk fermentation at $25^{\circ} \mathrm{C}$ for 90 minutes. After fermentation, the dough was manually moulded into $400 \mathrm{~g}$ balls and baked in an oven (Matador, Werner \& Pfleiderer Lebensmitteltechnik $\mathrm{GmbH})$ at $270{ }^{\circ} \mathrm{C}$ for $40 \mathrm{~min}$.

The Broa bread making process was performed using the same recipe that vary only in the maize flour used (11 OPVs and commercial flour), keeping the remaining ingredients and process identical.

The quality parameters of the twelve broa were measured the following day after its production by instrumental and sensory analysis.

\subsection{Broa bread evaluations}

Physical analysis (colour and texture)

The colour of the crumb and crust were measured at three different sample areas by using a Minolta Chromameter CR-2b. The colour was recorded using CIE with the following variables: $\mathrm{L}^{*}$ - lightness, $\mathrm{a}^{\star}-$ hue on a green $(-)$ to red $(+)$ axis, $\mathrm{b}^{\star}$ - hue on a blue (-) to yellow $(+)$ axis and $\Delta \mathrm{E}$ - colour total variation relative to a white surface reference (Pineli et al., 2015). Additionally, the cylindrical coordinates hue or hue angle $\left(\mathrm{h}_{\mathrm{ab}}\right)$ and Chroma $\left(C_{a b}^{*}\right)$ were defined by the following equations:

$h_{a b}=\arctan \left(b^{*} / a^{*}\right)$

$c_{a b}^{*}=\sqrt{\left(\left(a^{*}\right)^{2}+\left(b^{*}\right)^{2}\right)}$

where the hue angle is the angle for a point calculated from the $\mathrm{a}^{\star}$ and $\mathrm{b}^{\star}$ coordinates in the colour space (Equation 1 ) and the Chroma is the quantitative component of the colour (Equation 2; Kane et al., 2003), which reflects the purity of colour in the CIELAB space.

Bread slices (25-mm thickness) were procured to determine the crumb firmness using a compression test in a texture analyser (TA-Hdi, Stable Micro Systems, Godalming, UK). The firmness (in $\mathrm{g}$ force) was automatically recorded (12 measurements per loaf) by the data processing software on days 1, 3 and 7 after baking according to the AIB standard procedure. Three batches of each composition were prepared, and at least five measurements were performed on each batch (Vidigal et al., 2012).

Sensory analysis (appearance, colour, odour, flavour, texture by touch and mouthfeel, cohesiveness and global appreciation)

Sensory evaluation of the broa samples was conducted $24 \mathrm{~h}$ after their production using a hedonic quantitative response scale (International Organization for Standardization, 2003) in a test room (International Organization for Standardization, 2007) with a consumer panel of 52 assessors. The hedonic test was performed using a numeric category scale from 1 (extremely unpleasant) to 8 (extremely pleasant) for the following eight attributes: appearance (aspect), colour, odour, flavour, texture (by touch and mouthfeel), cohesiveness and global appreciation from 1 (much less than ideal) to 5 (more than ideal). The assessors were volunteers recruited primarily from research and educational institutes at the Oeiras campus, and their characterisation was organised by age, gender and place of birth. The assessors were also asked to declare if they did not have gluten intolerance and were regular consumers of broa bread. Each assessor participated in three separate sessions, scoring four broa bread samples (20 g sample size) per session with the presentation order randomized between and within assessors. Tap water and apples were served as a palate cleanser between samples.

Attributes that best reflect the assessments of 'broas' have been identified based on the comments recorded by the assessors, who referred to the bread (Callejo, 2011) and ISO 5492 
definitions (International Organization for Standardization, 2008) for appearance, odour, texture and flavour. The present study was approved by the Portuguese Institute for Agrarian and Veterinary Scientific board and also of Technical Standardization Committee for cereals and cereal derivatives.

\subsection{Statistical analysis}

The influence of maize flours OPVs origin in the broa physical and sensory differences were analysed using one-way analysis of variance (ANOVA). The means were classified by Duncan's multiple-range test $(\mathrm{p} \leq 0.05)$. Any significant linkage associations between the consumer panel respondents' variables (gender, age and region of born) and level of sensory analysis response by attribute were tested using the chi-square test. Individual assessor age, region and response data by attribute were grouped on three levels (unpleasant, pleasant, very pleasant), and contingency tables, Pearson chi-square and probabilities values were calculated by crosstabs. All of the procedures were computed using the statistical package SPSS (SPSS, V. 20.0).

\section{Results and discussion}

The slices from the twelve broa samples that were produced from the 11 maize OPVs and commercial maize flour (Figure 1) show perceived differences in their colouring.

\subsection{Physical analysis}

Analysis of the collected data by ANOVA showed that all of the instrumental analyses were able to distinguish between the broa breads tested $(\mathrm{p} \leq 0.05)$.

\section{Colour and firmness broa evaluation}

Table 1 presents the means of the colour obtained in the analysis of each broa.

The colour of the crumb is an important parameter for characterizing bread. A lower $\mathrm{L}^{\star}$ value indicates a darker crumb, a positive $\mathrm{a}^{\star}$ value is associated with crumb redness, and a positive $\mathrm{b}^{*}$ value indicates yellow colour. A strong correlation $\left(\mathrm{r}^{2}=0.993\right.$, $\mathrm{p}<0.01$ ) between the maize flour and bread crumb $b^{*}$ colour was observed. The broa breads presented with a negative $\mathrm{a}^{\star}$ value (hue on green axis), positive $b^{\star}$ value (hue on yellow axis), low variability in lightness and negative hue values, which reflect a yellow-greenish hue. Large variations with respect to $b^{*}$ and chroma values were observed between the broa samples (Table 1).

Castro verde, Fandango and Aljezudo broas showed $\mathrm{b}^{*}$ and chroma values higher than the other samples, which suggests their higher colour purity related to the major intensity of the yellow component.
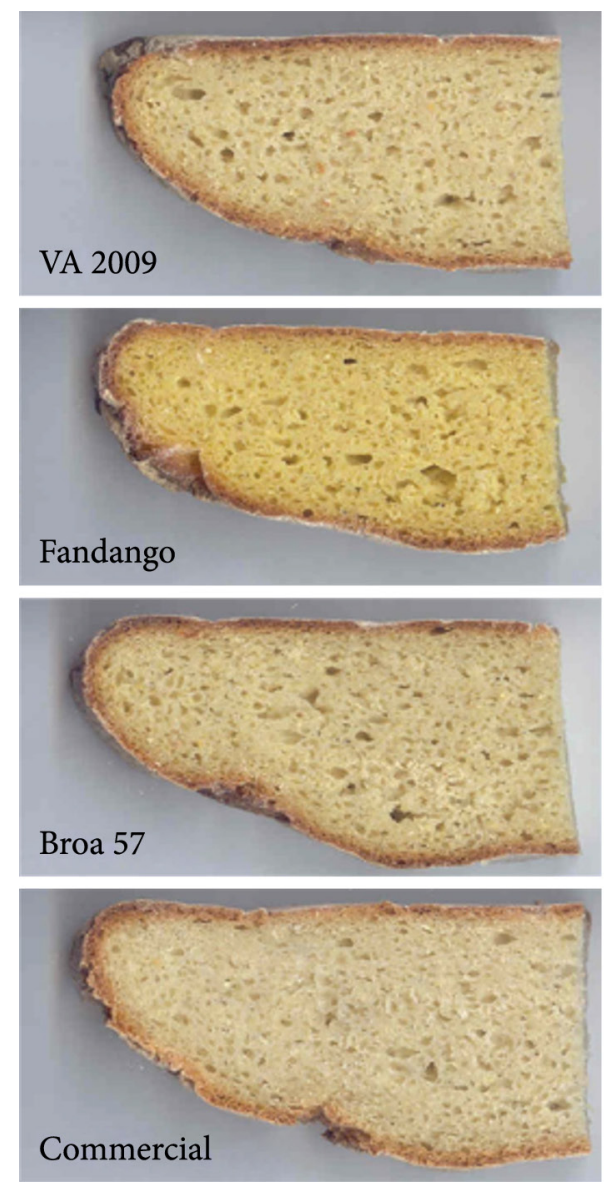
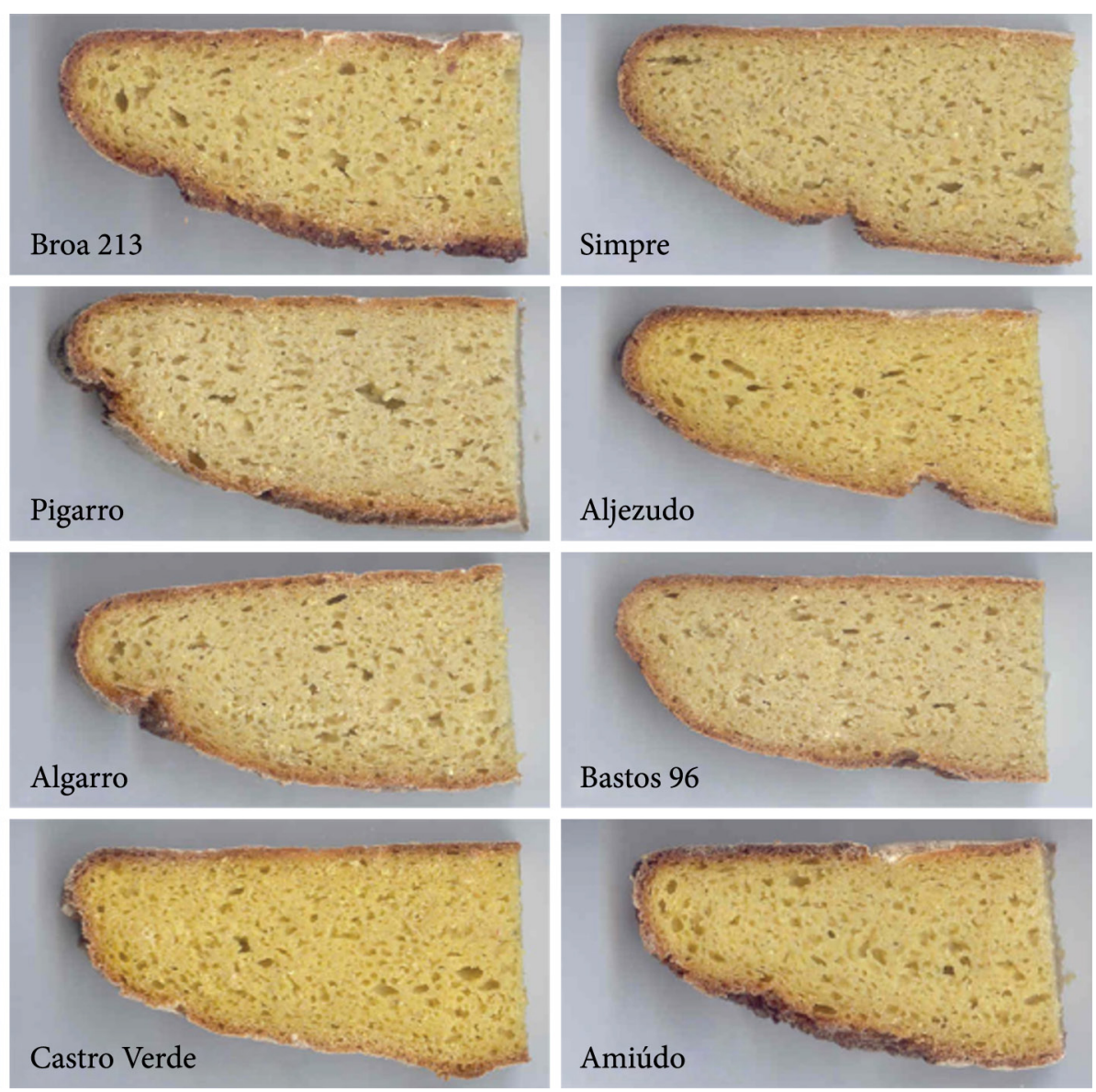

Figure 1. Images of sliced broa samples produced from the 11 maize OPVs and commercial flour broas. 
Table 1. Means and Duncan test classification of the colour of the analysed broa samples.

\begin{tabular}{|c|c|c|c|c|c|}
\hline & \multicolumn{3}{|c|}{ Colour bread crumb } & \multirow{2}{*}{$\begin{array}{c}\text { Chroma } \\
C_{a b}^{\star}\end{array}$} & \multirow{2}{*}{$\begin{array}{c}\text { Hue angle } \\
\mathbf{h}_{\mathrm{ab}}\end{array}$} \\
\hline & $\mathbf{L}^{*}$ & $\mathbf{a}^{*}$ & $\mathbf{b}^{*}$ & & \\
\hline Simpre & $64.6^{\mathrm{bcd}}$ & $-1.1^{\text {cdef }}$ & $24.9^{\mathrm{e}}$ & $24.9^{\mathrm{e}}$ & $-1.5^{\mathrm{abc}}$ \\
\hline Aljezudo & $63.6^{\mathrm{d}}$ & $-1.2^{\mathrm{def}}$ & $31.9^{\mathrm{b}}$ & $32.0^{\mathrm{b}}$ & $-1.5^{\mathrm{abc}}$ \\
\hline Bastos 96 & $65.9^{\mathrm{abc}}$ & $-0.7^{\mathrm{ab}}$ & $22.2^{\mathrm{f}}$ & $22.2^{\mathrm{f}}$ & $-1.5^{\mathrm{bc}}$ \\
\hline Amiúdo & $64.4^{\mathrm{d}}$ & $-0.7^{\mathrm{bc}}$ & $29.6^{c}$ & $29.6^{c}$ & $-1.6^{\mathrm{cd}}$ \\
\hline Broa 213 & $65.4^{\mathrm{abc}}$ & $-1.3^{\mathrm{g}}$ & $27.5^{\mathrm{d}}$ & $27.5^{\mathrm{d}}$ & $-1.5^{\mathrm{ab}}$ \\
\hline Pigarro & $66.6^{\mathrm{a}}$ & $-0.8^{\mathrm{bcd}}$ & $21.4^{\mathrm{fg}}$ & $21.4^{\mathrm{fg}}$ & $-1.5^{\mathrm{abc}}$ \\
\hline Algarro & $66.0^{\mathrm{ab}}$ & $-1.3^{\mathrm{ef}}$ & $24.3^{\mathrm{e}}$ & $24.3^{\mathrm{e}}$ & $-1.5^{\mathrm{a}}$ \\
\hline C. Verde & $65.3^{\mathrm{abc}}$ & $-0.3^{\mathrm{a}}$ & $35.5^{\mathrm{a}}$ & $35.6^{\mathrm{a}}$ & $-1.6^{\mathrm{d}}$ \\
\hline VA 2009 & $66.6^{\mathrm{a}}$ & $-0.9^{\text {bcde }}$ & $20.6^{\text {gh }}$ & $20.7^{\mathrm{gh}}$ & $-1.5^{\mathrm{abc}}$ \\
\hline Fandango & $65.4^{\mathrm{abc}}$ & $-0.8^{\mathrm{bcd}}$ & $32.4^{\mathrm{b}}$ & $32.5^{\mathrm{b}}$ & $-1.5^{\mathrm{cd}}$ \\
\hline Broa 57 & $65.6^{\mathrm{abc}}$ & $-0.6^{\mathrm{ab}}$ & $20.1^{\mathrm{h}}$ & $20.2^{\mathrm{h}}$ & $-1.5^{\mathrm{bc}}$ \\
\hline Commercial & $66.1^{\mathrm{ab}}$ & $-0.5^{\mathrm{ab}}$ & $15.1^{\mathrm{i}}$ & $15.2^{\mathrm{i}}$ & $-1.5^{\mathrm{abc}}$ \\
\hline
\end{tabular}

Parameter values followed by the same letter are not significantly different (Duncan, $p<0.05$ ).

The crust colour is highly related with Maillard reactions that take place in the oven during baking, and no significant differences between broas were observed.

In addition to the flour specifications and bread attractiveness aspects, the colour also has nutritional implications. Significant correlations between the $\mathrm{b}^{*}$ parameter and lutein contents, an important carotenoid with antioxidant properties and beneficial nutritional effects, have been identified (Brites et al., 2013). The commercial variety broa is white and has the lowest $\mathrm{b}^{*}$ value and lutein content $(1.2 \mu \mathrm{g} / \mathrm{g})$. In contrast, broa made from Castro verde presents a higher $b^{*}$ value due to its intense yellow colour and also shows higher lutein content $(19.5 \mu \mathrm{g} / \mathrm{g})$.

Crumb firmness was determined on days 1, 3 and 7, and the results obtained on days 1 and 3 show a significant increase in hardness for all of the sample breads, which is consistent with observations of other bread types (Ishida \& Steel, 2014) due to the loss of freshness derived from starch retrogradation (Figure 2).

Most of the sample breads show similar crumb firmness profile from day 3 to day 7; however, the Bastos 96 and VA 2009 broas showed increased shelf lives, whereas the Amiudo broa shelf life was decreased. The commercial broa presented higher crumb firmness and longer shelf life, whereas a softer broa was obtained with Aljezudo maize variety.

\subsection{Sensory analysis}

\section{Profile of consumer panel assessors}

The consumer panel assessors $(\mathrm{n}=52)$ with $23.15 \%$ males and $76.9 \%$ of females, was comprised of primarily women aged 20 to 50 years from Lisbon and the Vale do Tejo region (Figure 3).

The linkage associations between the sensory response by attribute and the consumer panel variables (gender, age, region of born) revealed significant influences of consumer age on the colour $\left(\mathcal{\varkappa}^{2}=10.913 ; p=0.028\right)$ and cohesiveness $\left(\mathcal{\varkappa}^{2}=15.131 ; p=0.004\right)$, whereas the birth region had influences on the appearance $\left(\varkappa^{2}=10.395 ; p=0.034\right)$ and texture $\left(\varkappa^{2}=16.006 ; p=0.003\right)$.

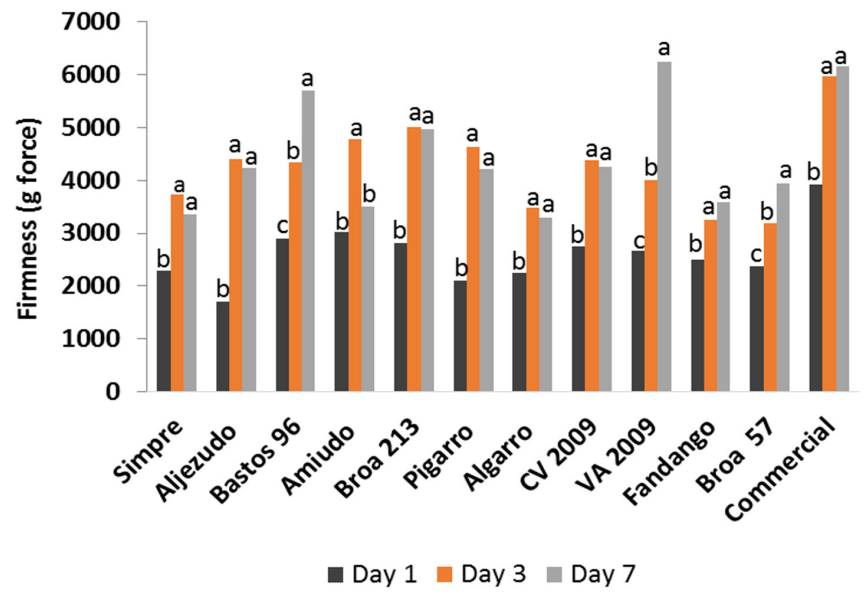

Figure 2. Means of the firmness ( $\mathrm{g}$ force) of the broa sample analysed on days 1, 3, and 7 after baking; days with the same letter are not significantly different (Duncan, $\mathrm{p}<0.05$ ).

Assessors aged between 31-50 years responded that the colour and cohesiveness were more pleasant than the younger assessors. Respondents from Lisbon and Vale do Tejo region gave higher scores for appearance and texture compared to panellists form other regions.

\section{Scoring of sensorial attributes}

According to the ANOVA results, the broa samples differed significantly $(\mathrm{p}<0.05)$ in appearance, odour, texture, flavour, colour and global appreciation. Despite this fact, the broa sensory analysis scores revealed poor discrimination of the different maize OPV and provided evidence that the commercial broa had the lowest mean scores for the evaluated attributes (Table 2).

In general, Castro verde broa scored higher for the majority of the sensorial attributes, but the Fandango broa matched the Castro verde's global appreciation score while achieving the highest appearance score. Additionally, Broa 57 recorded the highest flavour score. 

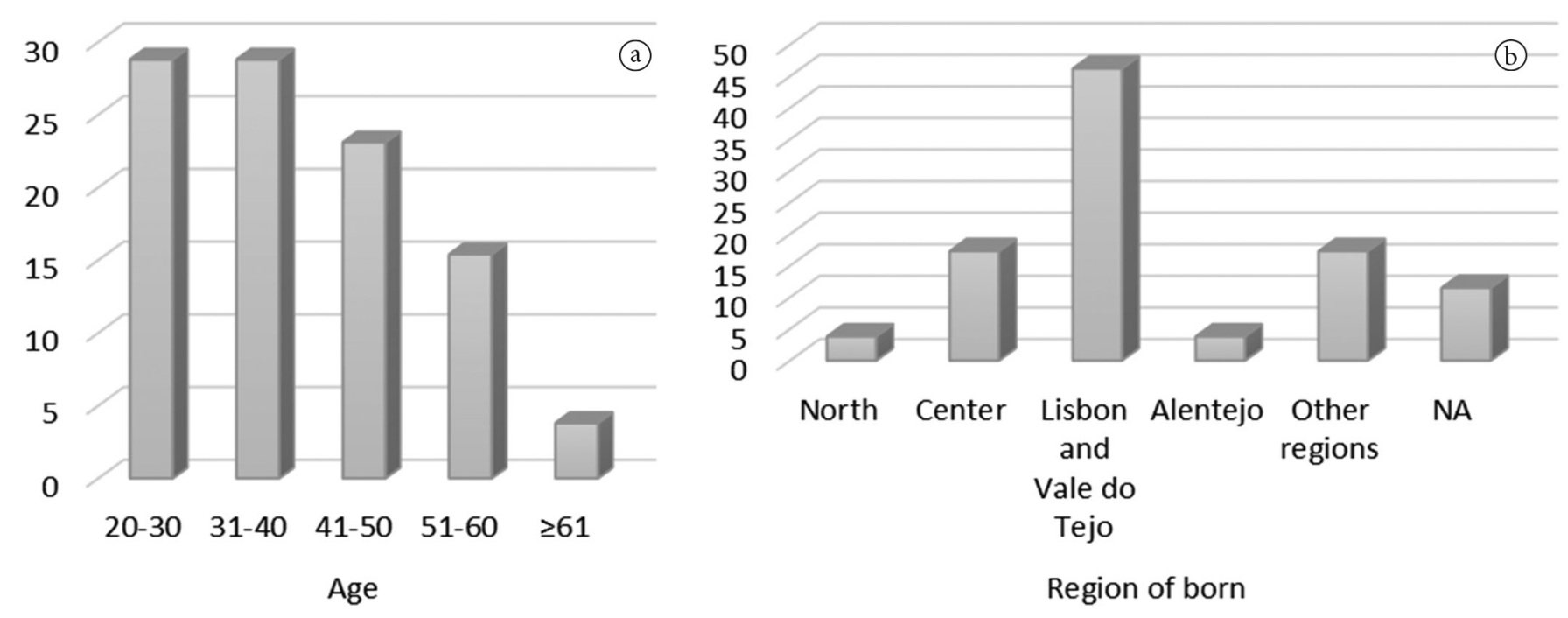

Figure 3. (a) Differentiation of the consumers based on age; (b) Region of born.

Table 2. Means and Duncan test classification for the sensory scores for appearance, odour, texture, flavour, colour, global appreciation and cohesiveness attributes of each broa sample analysed.

\begin{tabular}{|c|c|c|c|c|c|c|c|}
\hline & Appearance & Odour & Texture & Flavour & Colour & $\begin{array}{c}\text { Global } \\
\text { Appreciation }\end{array}$ & Cohesiveness \\
\hline Aljezudo & $6.47^{b c}$ & $5.87^{\mathrm{a}}$ & $6.17^{\mathrm{ab}}$ & $6.04^{\mathrm{bcd}}$ & $6.70^{\mathrm{ab}}$ & $6.06^{\mathrm{ab}}$ & $3.17^{\mathrm{a}}$ \\
\hline Amiúdo & $6.42^{\mathrm{bc}}$ & $5.98^{\mathrm{a}}$ & $6.30^{\mathrm{ab}}$ & $6.15^{\mathrm{bcd}}$ & $6.29^{c}$ & $6.12^{\mathrm{a}}$ & $3.02^{\mathrm{ab}}$ \\
\hline Broa 213 & $6.39^{a b c}$ & $5.85^{\mathrm{a}}$ & $6.13^{\mathrm{ab}}$ & $5.96^{\mathrm{bcd}}$ & $6.34^{\mathrm{bc}}$ & $6.02^{\mathrm{ab}}$ & $3.04^{\mathrm{ab}}$ \\
\hline Castro verde & $6.72^{\mathrm{a}}$ & $6.20^{\mathrm{a}}$ & $6.35^{\mathrm{a}}$ & $6.17^{\mathrm{bcd}}$ & $6.89^{\mathrm{a}}$ & $6.28^{\mathrm{a}}$ & $3.09^{\mathrm{ab}}$ \\
\hline VA 2009 & $5.98^{\mathrm{cd}}$ & $5.93^{\mathrm{a}}$ & $5.89 \mathrm{a}^{\mathrm{b}}$ & $5.84^{\mathrm{cd}}$ & $5.75^{\mathrm{d}}$ & $5.89^{\mathrm{ab}}$ & $2.95^{\mathrm{ab}}$ \\
\hline Fandango & $6.75^{\mathrm{a}}$ & $6.20^{\mathrm{a}}$ & $6.27^{\mathrm{ab}}$ & $6.20^{\mathrm{bc}}$ & $6.84^{\mathrm{a}}$ & $6.27^{\mathrm{a}}$ & $3.09^{\mathrm{ab}}$ \\
\hline Broa 57 & $6.97^{\mathrm{cd}}$ & $5.86^{\mathrm{a}}$ & $6.25^{\mathrm{ab}}$ & $6.36^{\mathrm{a}}$ & $5.70^{\mathrm{d}}$ & $6.20^{\mathrm{a}}$ & $3.07^{\mathrm{ab}}$ \\
\hline Commercial & $5.34^{\mathrm{e}}$ & $5.39^{\mathrm{b}}$ & $4.89^{c}$ & $4.67^{\mathrm{e}}$ & $4.98^{\mathrm{e}}$ & $4.54^{\mathrm{c}}$ & $2.82^{\mathrm{c}}$ \\
\hline
\end{tabular}

Means followed by the same letter are not significantly different (Duncan, $p<0.05$ ).

\section{Sensory quality responses}

Most of the positive comments were attributed to the broa made from Castro verde variety, with comments such as 'appealing colour', 'nice texture', 'ideal humidity' and 'most tasty'. In contrast, the majority of the negative comments were attributed to the broa made from commercial flour, including 'dry texture', 'weak typical flavour', 'with a weak maize flavour', 'no history'.

Sensory descriptors for appearance, odour, texture and flavour attributes

Table 3 summarises the proposed attributes considering the comments obtained from the 52 assessors, the visio-tactile perception and texture seems to be the most decisive criterion of consumer acceptability of broa. In fact, the texture of the bread crumb is related to the perception of quality (Gámbaro et al., 2002; Jensen et al., 2010).

\subsection{Relationship between instrumental and sensory evaluations}

Despite the hedonic sensory evaluation, strong linear relationships were observed with the instrumental colour parameters because the assessors assigned high scores to the intense yellow colours.

In Portugal, white bread consumption was preferred in the 1800 s due to its association with higher social class. Anyway, any value of the enjoyment of bread colour associated with life experience and memory remains objectively unexplained (Kihlberg \& Risvik, 2007).

Furthermore, concerning texture, the commercial broa had the highest firmness and worst sensorial evaluation, which denotes a good relationship between sensory appreciation and instrumental measurements. Similar results were reported on 
Table 3. Appearance, odour, proposed attributes and related comments obtained from the consumer panel sensory analysis of the broa samples.

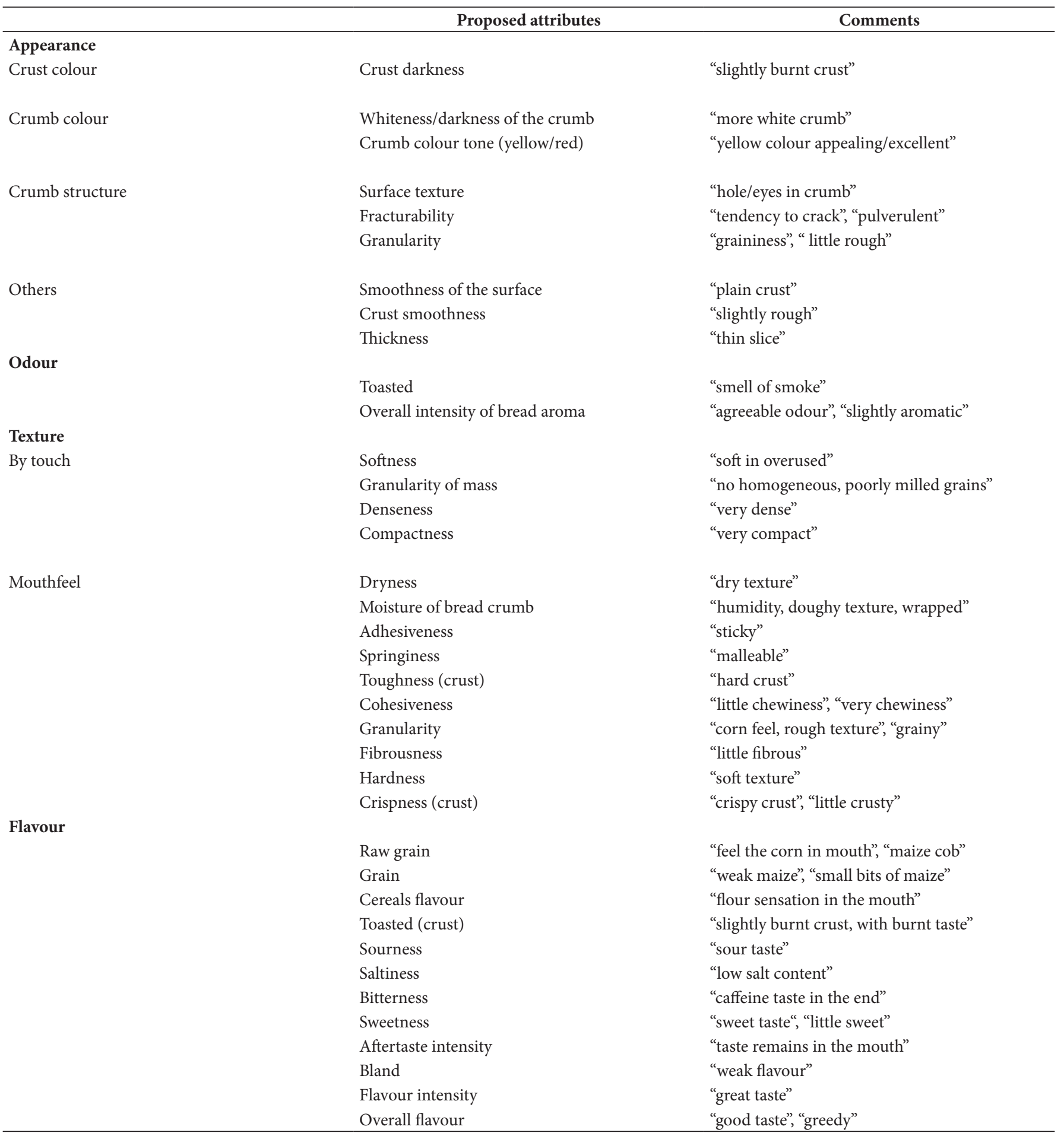

wheat bread analysis by Gámbaro et al. (2002) using a texture profile analysis.

The broa textural properties are significantly influenced by the particle size index of maize flours. The flour particle size distribution obtained on the Malvern multi-channel laser light-scatter instrument and expressed as medium diameter percentiles (d0.1, d0.5, d0.9) and volume weighted mean $\mathrm{D}[4.3]$ in $\mu \mathrm{m}$ were registered (Table 4 ).
The particle size $\mathrm{D}[4.3$ ] parameter of the maize flour and the firmness of the broas showed a positive correlation $(\mathrm{p}<0.01)$. The commercial maize flour broa exhibited the highest $\mathrm{D}$ [4.3] of $364 \mu \mathrm{m}$, which is on the higher end of the mean diameter distribution range, with $\mathrm{d} 0.1, \mathrm{~d} 0.5$, and $\mathrm{d} 0.9$ values of $16 \mu \mathrm{m}$, $250 \mu \mathrm{m}$ and $887 \mu \mathrm{m}$, respectively, as well as higher broa firmness (3920 g force, Figure 2). However, the Fandango flour broa showed the lowest $\mathrm{D}[4.3]$ of $211 \mu \mathrm{m}$ and a smaller range of 
Carbas et al.

Table 4. Particle size distribution of the eleven maize OPVs and commercial flour.

\begin{tabular}{|c|c|c|c|c|}
\hline OPV maize flour & $\mathrm{D}[4.3]$ & d0.1 & d0.5 & d0.9 \\
\hline Simpre & 241 & 20 & 166 & 532 \\
\hline Aljezudo & 311 & 40 & 261 & 645 \\
\hline Bastos & 231 & 30 & 160 & 508 \\
\hline Amiúdo & 329 & 43 & 273 & 694 \\
\hline Broa 213 & 295 & 40 & 222 & 642 \\
\hline Pigarro & 258 & 29 & 200 & 572 \\
\hline VA 2009 & 310 & 24 & 207 & 746 \\
\hline Fandango & 211 & 25 & 160 & 425 \\
\hline Broa 57 & 244 & 28 & 173 & 549 \\
\hline Commercial & 364 & 16 & 250 & 887 \\
\hline
\end{tabular}

mean diameter distribution, with $\mathrm{d} 0.1, \mathrm{~d} 0.5$, and $\mathrm{d} 0.9$ values of $25 \mu \mathrm{m}, 160 \mu \mathrm{m}$ and $425 \mu \mathrm{m}$, respectively. Similar results were obtained with the remaining OPV maize flours.

The odour and flavour of bread is detected by the release of aromatic substances from the bread into the orthonasal route (Callejo, 2011). Sourdough fermentation that occurs during the process of baking broa produces more aromatic compounds and flavour components than traditional yeast leavened breads, primarily in the crumb, whereas the flavour products originating from the thermal reaction dominate in the crust (Gänzle et al., 2008).

The most potent odorants of wheat bread crumb have been identified as 2-phenylethanol (E)-2-nonenal and (E,E)-2,4-decadienal (Grosch \& Schieberle, 1997), which are two aldehydes known as antioxidant products of linoleic acid and are responsible for the fatty smell. The broa formulation described above includes rye flour. The most intense and bread-like flavour notes of sourdough rye bread crumbs have been associated with the volatile compounds 2-propanone, 3-methyl-1-butanal, benzyl alcohol and 2-phenylethanol (Hansen et al., 1989). 2-phenylacetaldehyde has been suggested to be a key odorant for rye bread crumb and methional for rye bread crust (Schieberle, 1996).

The 2-acetyl-1-pyrroline (ACPY) is a popcorn-like key odorant evoking the roasted note of the aroma profile of wheat bread crust (Grosch \& Schieberle, 1997). Different concentrations of ACPY have been identified in wheat bread crust and crumb, which might be explained by a burst of yeast cells induced by the high temperature in the crust. This might lead to a release of ornithine (the baker's yeast amino acid precursor of the ACPY) and the formation of ACPY (Grosch \& Schieberle, 1997). Rye bread crust is very low in ACPY and much higher in 3-methylbutanal, methional, 4-hydroxy-2,5-dimethyl-3(2H)furanone compared to wheat bread. These differences in the concentrations of potent odorants are most likely responsible for the differences in the overall odours of wheat and rye bread crust (Grosch \& Schieberle, 1997).

A perceived sourness of broa is closely related with the concentrations of lactic and acetic acids primarily from sourdough lactic fermentation. The wholemeal maize flour also contributes to the acidification of sourdough and the strengthening of the rye-like flavour, which is also influenced by free phenolics acids present in the outer layers of the rye grain (Heiniö et al., 2008).

The phenolic content of maize flours and breads has been quantified using the Folin assay. Among the different maize flours, Bastos presented the highest free phenolic content $(101.74 \pm 15.67 \mathrm{mg} \mathrm{GAE}$ (gallic acid equivalents)/100 g dw) and Amiúdo the lowest phenolic content $(66.33 \pm 1.85 \mathrm{mg}$ $\mathrm{GAE} / 100 \mathrm{~g} \mathrm{dw})$. These results are in agreement with the values reported by Lopez-Martinez et al. (2011) for white maize samples and higher than the values described by Mora-Rochin et al., 2010, who reported a total phenolic content (free and bound phenolics) between 137.7 and $167.4 \mathrm{mg} \mathrm{GAE} / 100 \mathrm{~g} \mathrm{dw}$. As far as broa is concerned, the Aljezudo 2006 maize variety showed the lowest phenolic content (152.16 $\pm 3.04 \mathrm{mg} \mathrm{GAE} / 100 \mathrm{~g} \mathrm{dw})$ and Broa 57 the highest content $(225.08 \pm 28.10 \mathrm{mg} \mathrm{GAE} / 100 \mathrm{~g} \mathrm{dw})$. However, the sensory analysis of these broas shows assessments of spicy, slightly sour and bitter in the Aljezudo 2006 broa and no relevant flavours for Broa 57. In fact, the phenolic content quantified by Folin are the free compounds, which are soluble in the extract, but other phenolic compounds present in maize flours are bound, and the insoluble compounds (Mora-Rochin et al., 2010) are released to some extent during baking and are likely responsible for the differences in the flavour detected.

\subsection{Sensory panel profile vs comments recorded}

As a result of analysis of the panel profile and comments recorded by the 52 assessors, we observed that most broa consumers are traditional by nature whose values are connected to food choice motives, such as 'familiarity', 'natural content', 'ethical concern', where to some extent a preference is the result of personal experience (Pohjanheimo et al., 2010). Consumer perceptions of broa involve to a large extent personal experiences, interactions between sensory signals and feelings. What is remembered and not just what is consciously perceived during the moment of eating is the reason for the difficulty to identify, describe and access specific words for odours and flavours.

Broa has a dense texture with higher degree of mastication resistance, which is likely to negatively influence its consumption by hedonistic consumers who prefer bread with higher smoothness, 
elasticity and juiciness. However, for traditional consumers, broa is 'familiar', and strategic market communication should combine this affinity value with the fact that broa consumption should be highly recommended because of its beneficial effect on satiety and health (Brites et al., 2011).

\section{Conclusions}

The results obtained depict that broa made from commercial maize flour have lowest mean score for all the attributes, the reason being related flour particle size distribution as commercial flour had highest mean diameter and large particle distribution range.

This study is a first known approach of consumer perceived product characteristics of broa, with correlations observed for age and the birth region, and the definition of specific attributes for broa appearance, odour, texture and colour.

The Castro verde landrace variety was best among all the varieties tested for Broa making and should be indicated for eventual protected geographical indication.

The traditional consumers highlighted the poor quality of commercial flour and memory values associated with broa quality. This is useful knowledge for marketing communication design where values may be used as a tool to stimulate sustainable broa production and consumption.

This study showed that texture is the most relevant attribute for consumer acceptability of specialty maize bread broa and is associated with the flour particle size distribution, which depends on the maize type. These results are relevant to the use of maize flours in breadmaking as in gluten free formulations.

\section{Acknowledgements}

Financial support of SOLIBAM- Strategies for Organic and Low-input Integrated Breeding and Management, FP7 KBBE-245058 and PTDC/AGR-ALI/099285/2008, Fundação para a Ciência e Tecnologia (FCT). The publication costs are funded through the OpenAIRE project (Horizon 2020, grant agreement no. 643410). Technical assistance of sensory analyses of PROSENSE enterprise and assessors of sensory panel.

\section{References}

American Association of Cereal Chemists - AACC. (1999). Method 55-40.01:1999: approved methods of analysis: particle size of wheat flour by laser instrument (11th ed.). St. Paul.

Brites, C. M., Trigo, M. J., Carrapico, B., Alviña, M., \& Bessa, R. J. (2011). Maize and resistant starch enriched breads reduce postprandial glycemic responses in rats. Nutrition Research, 31(4), 302-308. http://dx.doi.org/10.1016/j.nutres.2011.02.001. PMid:21530804.

Brites, C., Carbas, B., Faustino, J., Bronze, M. R., Silva, A., Veiga, H. I. M., Mendes-Moreira, P., Rodrigues, J. C., Simões, R., Meneses, J. C., \& Vaz-Patto, M. C. (2013). Exploring food quality traits diversity on portuguese maize inbred lines. In Proceedings ICC/AGSA Grains For Quality Of Life Conference (pp. 2), Perth, Australia. Section Poster 1: cereals, pulses and new grains.

Brites, C., Haros, M., Trigo, M. J., \& Islas, R. P. (2007). Maíz. In A. E. León. \& C. M. Rosell (Eds.). De tales harinas, tales panes: granos, harinas y productos de panificación en Iberoamérica (pp. 74-121). Córdoba: Hugo Báez.

Brites, C., Trigo, M. J., Santos, C., Collar, C., \& Rosell, C. M. (2010). Maize-based gluten-free bread: influence of processing parameters on sensory and instrumental quality. Food Bioprocess Technology, 3(5), 707-715. http://dx.doi.org/10.1007/s11947-008-0108-4.

Callejo, M. J. (2011). Present situation on the decriptive sensory analysis of bread. Journal of Sensory Studies, 26(4), 255-268. http://dx.doi. org/10.1111/j.1745-459X.2011.00341.x.

Gámbaro, A., Varela, P., Gimenez, A., Aldrovandi, A., Fiszman, S. M., \& Hough, G. (2002). Textural quality of white pan bread by sensory and instrumental measurements. Journal of Texture Studies, 33(5), 401-413. http://dx.doi.org/10.1111/j.1745-4603.2002.tb01356.x.

Gänzle, M. G., Loponen, J., \& Gobbetti, M. (2008). Proteolysis in sourdough fermentations: mechanisms and potential for improved bread quality. Trends in Food Science \& Technology, 19(10), 513-521. http://dx.doi.org/10.1016/j.tifs.2008.04.002.

Grosch, W., \& Schieberle, P. (1997). Flavour of cereal products: a review. Cereal Chemistry, 74(2), 91-97. http://dx.doi.org/10.1094/ CCHEM.1997.74.2.91.

Hansen, B., Lund, B., \& Lewis, M. J. (1989). Flavor of sourdough rye bread crumb. Lebensmittel Wiss Technology, 22, 141-144.

Heiniö, R.-L., Liukkonen, K.-H., Myllymäki, O., Pihlava, J.-M., Adlercreutz, H., Heinonen, S.-M., \& Poutanen, K. (2008). Quantities of phenolic compounds and their impacts on the perceived flavour attributes of rye grain. Journal of Cereal Science, 47(3), 566-575. http://dx.doi. org/10.1016/j.jcs.2007.06.018.

International Organization for Standardization - ISO. (2003). ISO 41212: sensory analysis: guidelines for the use of quantitative response scales: sensory analysis. Geneva.

International Organization for Standardization - ISO. (2007). ISO 8589: sensory analysis: general guidance for the design of test rooms: sensory analysis. Geneva.

International Organization for Standardization - ISO. (2008). ISO 5492: sensory analysis: vocabulary: sensory analysis. Geneva.

Ishida, P. M. G., \& Steel, C. J. (2014). Physicochemical and sensory characteristics of pan bread samples available in the Brazilian market. Food Science and Technology, 34(4), 746-754. http://dx.doi. org/10.1590/1678-457X.6453.

Jensen, S., Oestdal, H., \& Thybo, A. K. (2010). Sensory profiling of changes in wheat and whole wheat bread during a prolonged period of storage. Journal of Sensory Studies, 25(2), 231-245. http://dx.doi. org/10.1111/j.1745-459X.2009.00254.x.

Justino, D. (1988). A formação do espaço económico nacional: Portugal 1810-1913 (Vol. I). Lisboa: Veja.

Kane, A. M., Lyon, B. G., Swanson, R. B., \& Savage, E. M. (2003). Comparison of two sensory and two instrumental methods to evaluated cookie colour. Journal of Food Science, 68(5), 1831-1837. http://dx.doi.org/10.1111/j.1365-2621.2003.tb12338.x.

Kihlberg, I., \& Risvik, E. (2007). Consumers of organic foods. Value segments and liking of bread. Food Quality and Preference, 18(3), 471-481. http://dx.doi.org/10.1016/j.foodqual.2006.03.023.

Kihlberg, I., Ostrom, A., Johansson, L., \& Risvik, E. (2006). Sensory qualities of plain white pan bread: Influence of farming system, milling and baking technique. Journal of Cereal Science, 43(1), 1530. http://dx.doi.org/10.1016/j.jcs.2005.04.008.

Lopez-Martinez, L. X., Parkin, K. L., \& Garcia, H. S. (2011). Phase II-inducing, polyphenols content and antioxidant capacity of corn (Zea mays L.) from phenotypes of white, blue, red and purple colors processed into masa and tortillas. Plant Foods for Human 
Nutrition, 66(1), 41-47. http://dx.doi.org/10.1007/s11130-0110210-z. PMid:21327968.

Matos, M. E., \& Rosell, C. M. (2012). Relationship between instrumental parameters and sensory characteristics in gluten-free breads. European Food Research and Technology, 235(1), 107-117. http:// dx.doi.org/10.1007/s00217-012-1736-5.

Meilgaard, M., Civille, G. V., \& Carr, B. T. (1999). Sensory evaluation techniques (3rd ed.) Boca Raton: CRC Press.

Mora-Rochin, S., Gutiérrez-Uribe, J. A., Serna-Saldivar, S. O., SánchezPeña, P., Reyes-Moreno, C., \& Milán-Carrillo, J. (2010). Phenolic content and antioxidant activity of tortillas produced from pigmented maize processed by conventional nixtamalization or extrusion cooking. Journal of Cereal Science, 52(3), 502-508. http://dx.doi. org/10.1016/j.jcs.2010.08.010.

Pineli, L. L. O., Moretti, C. L., Chiarello, M., \& Melo, L. (2015). Influence of strawberry jam color and phenolic compounds on acceptance during storage. Revista Ceres, 62(3), 3. http://dx.doi.org/10.1590/0034737X201562030002.

Pohjanheimo, T., Paasovaara, R., Luomala, H., \& Sandell, M. (2010). Food choice motives and bread liking of consumers embracing hedonistic and traditional values. Appetite, 54(1), 170-180. http:// dx.doi.org/10.1016/j.appet.2009.10.004. PMid:19835923.
Schieberle, P. (1996). Intense aroma compounds: useful tools monitor the influence of processing and storage on bread aroma. Advances in Food Science, 18, 237-244.

Vaz Patto, M. C., Alves, M. L., Almeida, N. F., Santos, C., Mendes-Moreira, P., Satovic, Z., \& Brites, C. (2009). Is the bread making technological ability of Portuguese traditional maize landraces associated with their genetic diversity? Maydica, 54, 297-311.

Vaz Patto, M. C., Mendes-Moreira, P. M., Alves, M. L., Mecha, E., Brites, C., Bronze, M. R., \& Pego, S. (2013). Participatory plant quality breeding: an ancient art revisited by knowledge sharing. In S. B. Andersen (Ed.). The portuguese experience: in plant breeding from laboratories to fields. Croatia: InTech.

Vaz Patto, M. C., Moreira, P. M., Carvalho, V., \& Pego, S. (2007). Collecting maize (Zea mays L. convar. mays) with potential technological ability for bread making in Portugal. Genetic Resources and Crop Evolution, 54(7), 1555-1563. http://dx.doi.org/10.1007/s10722-006-9168-3.

Vidigal, M. C. T. R., Minim, V. P. R., Ramos, A. M., Ceresino, E. B., Diniz, M. D. M. S., Camilloto, G. P., \& Minim, L. A. (2012). Effect of whey protein concentrate on texture of fat-free desserts: sensory and instrumental measurements. Food Science and Technology, 32(2), 412-418. 